\title{
Insure them and improve their welfare: effect of Hygeia Community Health Insurance on households' welfare in Kwara State, Nigeria
}

\author{
Raphael BABATUNDE*, Adeyemi OMONIWA and Oluwafemi OYEDEJI
}

Received February 11, 2017; accepted January 23, 2019.

Delo je prispelo 11. februarja 2017, sprejeto 23. januarja 2019.

\begin{abstract}
The Hygeia Community Health Plan was designed such that agriculture-based households can have access to affordable healthcare services. It is also aimed at providing financial risk protection against catastrophic healthcare costs which if persistent, could possibly drive them into poverty. This paper used a well-structured questionnaire to solicit responses on the effect of the Hygeia Community Health Plan on the welfare of farming households in Kwara State, Nigeria. A two-stage sampling technique was used to sample 175 farming households comprising of 115 beneficiaries and 60 nonbeneficiaries from Shonga, Bacita and Lafiagi districts of Edu local government area of Kwara State, Nigeria. The ordinary least square and logit model were used in the analysis of the data for this study. The results of the analysis showed that the Hygeia community health plan was positively and statistically significant in influencing the per capita income, per capita calorie intake and the food security status of farming households in the area. Therefore, it was recommended that the government should create an enabling environment or partner with private insurance organizations. This will help them work out a plan to help rural households in other parts of the country access affordable healthcare services easily. This will help in the attainment of the universal access to health services in Kwara State and country Nigeria at large.
\end{abstract}

Key words: Hygeia; health plan; community; welfare and farming; Kwara state; Nigeria

\author{
IZVLEČEK
}

\author{
ZAVARUJ JIH IN IZBOLJŠAJ NJIHOVO \\ ZDRAVSTVENO VARSTVO: UČINEK \\ ZDRAVSTVENEGA ZAVAROVANJA HYGEIA NA \\ DOBROBIT GOSPODINJSTEV V DRŽAVI KWARA, \\ NIGERIA
}

Zdravstveni plan skupnosti Hygeia je bil zasnovan tako, da imajo pretežno kmetijska gospodinjstva dostop do ugodnih zdravstvenih storitev. Njegov namen je bil tudi zaščita pred finančnimi tveganji, ki nastajajo ob naraščajočih stroških zdravstvenega zavarovanja, ki bi zavarovance lahko pahnili v revščino. Prispevek je nastal na osnovi dobro zasnovanega vprašalnika za preučitev odgovorov, ki so jih dali izprašanci na učinke zdravstvenega plana skupnosti Hygeia na dobrobit kmečkih gospodinstev v državi Kwara, Nigeria. Uporabljena je bila dvostopenjska vzorčevalna tehnika, v kateri je sodelovalo 175 kmečkih gospodinjstev, 115 upravičencev in 60 neupravičencev zdravstvenega sklada iz okrožij Shonga, Bacita in Lafiagi, Edu lokalne vladne enote v državi Kwara, Nigeria. Za obdelavo podatkov sta bila $\mathrm{v}$ tej raziskavi uporabljena linearni regresijski model (OLS-ordinary least squaeres) in logistični model. Rezultati so pokazali, da je Hygeia komunalni zdrastveni plan statistično značilno pozitivno vplival na prihodek na prebivalca in vnos kalorij, kar je izboljšalo prehransko varnost kmečkih gospodinjstev na območju. Zaradi tega priporočamo vladi, da oblikuje ustrezno vspodbudno okolje ali se poveže z zasebnimi zavarovalnicami. To bi pomagalo izdelati plan dostopnega zdravstvenega servisa za kmečka gospodinjstva na podeželju tudi v drugih predelih dežele. Pripomoglo bi tudi doseči univerzalen dostop do zdravstvenih storitev v državi Kwara in širše v Nigeriji.

Ključne besede: Hygeia; zdravstveni plan; skupnost; dobrobit in kmetovanje; država Kwara, Nigerija

\section{INTRODUCTION}

Farming households in Nigeria constitute over 70 per cent of the country's rural population, most of which are deprived of access to quality health facilities that are essential for good living (Ajilowo, 2007). Some of the

1 Department of Agricultural Economics and Farm Management, University of Ilorin, Ilorin, Nigeria; *corresponding author: ralphag20@yahoo.com 
major consequences of this have been the migration to urban areas for medical treatment, the loss of about 25 per cent of their annual income to the treatment of various grades of sicknesses, increase risk of mortality of both children and adult, impaired productivity of able men and women among others. The World Health Assembly in 1988 mandated provision of sound health for all people by 2000 as the main target for all governments (WHO, 1997). This is because sound health is a fundamental requirement for leading a socially and economically productive life. However, many low-income countries have not been able to meet the basic healthcare needs of their people, especially those in the rural areas. In Nigeria, persistently low quality and inadequacy of health services provided in public facilities are some of the problems facing the health sector. Similarly, the state of the Nigerian health system can be said to be dysfunctional and grossly under-funded with a per capita expenditure of US\$ 9.44 (World Bank, 2005). As a result, Nigeria still has one of the worst health indices in the world and sadly accounts for 10 per cent of the world's maternal deaths in childbirth. The National health management information system is still weak, without an integrated system for disease surveillance, prevention and management (UNICEF, 2008).

Poor access to healthcare by farming households is not only due to inadequate or absence of health facilities. It can also be attributed to low purchasing power evidenced by their earnings and expenditure patterns. This is because they predominantly finance healthcare services out -of -pocket (Ogbimi, 2004 and Ataguba et al., 2006). Out-of-pocket costs are those health-care expenses paid that are not reimbursed by any health insurance company. Examples of common out-ofpocket costs include deductible, co-pay, and coinsurance. A health plan therefore is expected to "cap" out-of-pocket expenses. This means that once the maximum out-of-pocket cost for plan is reached, health plan takes over and provides coverage.

The Hygeia Community Health Plan is a form of health insurance plan designed to reduce economic difficulties following illness or injury. It evolved out of the aspirations of Hygeia Nigeria Limited and PharmAccess Foundation (A Dutch Non-Governmental Organization) to scale up HIV and AIDS care in Africa. Both parties decided that HIV and AIDS care should be provided within an integrated healthcare delivery framework as opposed to the more prevalent vertical disease models. It was also conceptualized that this integrated healthcare delivery framework would best be sustained and maintained within the context of a health insurance scheme. The scheme subsidizes premiums which were intended to facilitate the entry of individuals who were usually poor or had been impoverished by the disease.
This subsequently gave rise to Hygeia Community Health Plan (HCHP); a demand-drive, donor subsidized community health insurance scheme for low to medium income populations of Nigeria. The scheme was launched in January 2007 and it commenced operations in February 2007. The HCHP is currently the local implementation partner of the Dutch Health Insurance Fund in Nigeria. The Fund has pledged funding for the co-premiums of 115,000 low income individuals over a period of 5 years. The HCHP worked with the Fund, the World Bank and some state governments such as Kwara state on extending coverage to the low income people which comprises of farming households.

The success of any micro-insurance program such as the Hygeia Community Health Plan depends on its ability to improve economic outcomes among others while maintaining financial sustainability. It also assures donors that their money is being spent in the most efficient way possible. The Hygeia Community Health Plan focuses specifically on those rural households that are engaged in agricultural and non-agricultural production as a form of livelihood. At the household level, farming household are expected to have at least a source of capital which may be natural, physical, social, human, or financial (cash, credit/debit, savings) capital. Together these assets constitute a stock of resources used to generate well-being (Rakodi, 1999). Thus, this is expected to have significant impacts on their welfare and other resultant outcomes (Jansen et al., 2005). For example, some of these households may combine their assets with the benefits from Hygeia Community Health Plan to ensure an improvement in productivity and income that will result in improvement in their welfare.

Improved welfare which refers to a state of being happy, healthy and successful cannot be accomplished when households still have to pay exorbitant prices for healthcare. Agricultural production results in various degrees of hurt and illnesses which usually increase medical expenses and reduce income (Gertler et al., 2003). Thus resulting in a situation where households forgo qualitative care, yet they still pay substantial sums for low quality care (Das et al, 2008). High health care expenditures mean short-term health shock and can lead to debt, asset sales thus further plunging them in poverty (Annear, 2006). Furthermore, higher incidences of poverty in most rural areas in Nigeria have been traced to lack of appropriate insurance against income shocks. This is even worse because some farmers dispose their productive assets to meet immediate health consumption needs (Alayande and Alayande, 2004). This article therefore examines the extent to which enrolment in Hygeia Community Health Plan affects the welfare of farming households in Kwara State, Nigeria. This will add to the growing body of evidence on the effect of health insurance on households' welfare in Nigeria. 
Some of the available studies on the impact of coping strategies (Insurance inclusive) on household livelihoods outcomes have generally focused on food security as the livelihood indicator. Households were found to respond to food insecurity caused by shocks and stresses through reduction in quantity, composition and quality of foods consumed and the collection of wild foods. Others are the reduction in daily meal frequency, borrowing from relatives, and interhousehold food transfer to name a few (Mishra, 2007; Smucker \& Wisner, 2008). Against these background, the research question addressed in this paper are; Does enrollment health insurance plan (such as Hygeia Community Health plan) have any effect on the per capita income, per capita calorie intake and food security status of households? If yes, to what extent?

\section{MATERIALS AND METHODS}

\subsection{Study Area}

The study was conducted in Kwara State whose capital is Ilorin which has total land area of about $32,500 \mathrm{~km}^{2}$, and an estimated population of about 2.37 million people (NPC, 2008) out of which farmers account for about 70 per cent. The average population density of the state in 2006 was about 73 people per square kilometer. The farming system in the state is characterized by low quality but surplus land, low population density and cereal based cropping pattern. Agricultural production is largely peasant and small scale relying heavily on the use of manual labour equipped with crude implements. Landholding in the state is very small and most of the households have less than two hectares of land for farming. The output from this land is low and most households have to buy food when their own production is insufficient. Some of the rural households also participate in credit programs to supplement their household's income (KWSG, 2006).

\subsection{Data and Sample Size}

Study used primary data collected in 2014 through a proportionate sampling of 175 farming households from Shonga, Bacita and Lafiagi districts of Edu local government of the state. This comprises of 115 beneficiaries and 60 non-beneficiaries. Edu local government area of Kwara state was selected because it is one of the areas currently benefitting from the Hygeia Community Health Plan in the State. Data were collected on a wide range of variables using wellstructured questionnaire and personal interview method where appropriate.

\subsection{Analytical tools}

Descriptive statistics: The descriptive statistics used include measures of mean and frequency distribution. The mean is a measure of central tendency.

Ordinary least square (OLS) regression method: This was used to analyze the effect of the Hygeia health plan on two welfare indicators. The indicators considered are the Per Capita Income (PCI) and Per
Capita Calorie Intake (PCCI). The econometric model that was employed is implicitly stated as follow:

$\mathrm{Y}=f\left(\mathrm{X}_{1}, \mathrm{X}_{2}, \mathrm{X}_{3}, \mathrm{X}_{4}, \mathrm{X}_{5}, \mathrm{X}_{6}, \mathrm{X}_{7}, \mathrm{X}_{8}, \ldots \ldots \mathrm{U}\right)$

Where,

$\mathrm{Y}=$ Per Capita Income/ Per Capita Calorie Intake

Per capita calorie intake is expressed in (Kcal/AE/Day)

Per capita income is expressed in Naira

$\mathrm{X}_{1}=$ Gender of Household Head $(\mathrm{F}=0, M=1)$

$\mathrm{X}_{2}=$ Educational status of Household Head (Years of schooling)

$\mathrm{X}_{3}=$ Age of Household Head (Years)

$\mathrm{X}_{4}=$ Farm Size (Hectares)

$\mathrm{X}_{5}=$ Farming experience (Years)

$\mathrm{X}_{6}=$ Household size (Adult Equivalent)

$\mathrm{X}_{7}=$ Total monthly per capita expenditure of household

(Naira)

$\mathrm{X}_{8}=$ Access to credit (yes $=1,0$ otherwise)

$\mathrm{X}_{9}=$ Hygeia insurance scheme $($ Beneficiary $=1,0$ otherwise)

$\mathrm{U}=$ Random error term

Logit model: This was used to analyze the effect of the Hygeia health plan on the food security status of the farming households. To determine the food security status of households, a daily recommended per capita calorie intake of $2500 \mathrm{kcal} / \mathrm{AE} /$ day was adopted by the study as the food security line (FAO, 2005). In line with this, households that consumes less than the recommended calorie intake were classified as being food insecure while, households that consumes at least the recommended value were classified as food secure. The food security indicator (FSI) was measured in such a way that a food secure household takes the value of 1 while food insecure household takes 0 .

$\mathrm{Y}=f\left(\mathrm{X}_{1}, \mathrm{X}_{2}, \mathrm{X}_{3}, \mathrm{X}_{4}, \mathrm{X}_{5}, \mathrm{X}_{6}, \ldots . \mathrm{U}\right)$

Where,

$\mathrm{Y}=$ Food Security Status (Food secure $=1,0$ otherwise)

$\mathrm{X}_{1}=$ Age of Household Head (years)

$\mathrm{X}_{2}=$ Years of schooling of household head

$\mathrm{X}_{3}=$ Household size (Adult Equivalent) 
Raphael BABATUNDE et al.

$\mathrm{X}_{4}=$ Total monthly per capita expenditure (Naira)

$\mathrm{X}_{6}=$ Hygeia health plan $(\mathrm{Yes}=1, \mathrm{No}=0)$.

$\mathrm{X}_{5}=$ Farm size (hectares)

$\mathrm{U}=$ Error term

\section{RESULTS AND DISCUSSION}

\subsection{Socio-economic Characteristics}

Table 1: Socio-economic Characteristics

\begin{tabular}{|c|c|c|}
\hline Variables & Frequency & Percentage \\
\hline \multicolumn{3}{|l|}{ Age (years) } \\
\hline$\leq 30$ & 43 & 24.6 \\
\hline $31-45$ & 70 & 40.0 \\
\hline $46-60$ & 51 & 29.1 \\
\hline$>60$ & 11 & 6.3 \\
\hline \multicolumn{3}{|l|}{ Gender } \\
\hline Female & 4 & 2.3 \\
\hline Male & 171 & 97.7 \\
\hline \multicolumn{3}{|l|}{ Educational level } \\
\hline No formal Education & 43 & 24.6 \\
\hline Primary Education & 65 & 37.1 \\
\hline Junior Secondary & 7 & 4.0 \\
\hline Senior Secondary & 35 & 20.0 \\
\hline Tertiary & 25 & 14.3 \\
\hline \multicolumn{3}{|l|}{ Marital Status } \\
\hline Single & 10 & 5.7 \\
\hline Married & 160 & 91.4 \\
\hline Widowed/Separated & 5 & 2.9 \\
\hline \multicolumn{3}{|c|}{ Household size (Adult Equivalent) } \\
\hline$<3$ & 33 & 18.9 \\
\hline $3-6$ & 106 & 60.6 \\
\hline$>6$ & 36 & 20.5 \\
\hline \multicolumn{3}{|l|}{ Farm size (hectares) } \\
\hline$<3$ & 102 & 58.3 \\
\hline $3-6$ & 70 & 40.0 \\
\hline$>6$ & 3 & 1.7 \\
\hline \multicolumn{3}{|l|}{ Farm Experience (years) } \\
\hline$\leq 10$ & 35 & 20.0 \\
\hline $11-20$ & 66 & 37.7 \\
\hline $21-30$ & 48 & 27.4 \\
\hline$>30$ & 26 & 14.9 \\
\hline \multicolumn{3}{|c|}{ Membership of Cooperative Societies } \\
\hline Non-member & 109 & 62.3 \\
\hline Member & 66 & 37.7 \\
\hline \multicolumn{3}{|c|}{ Monthly Per Capita Income (N’000) } \\
\hline$<5$ & 130 & 74.5 \\
\hline $5-10$ & 37 & 21.1 \\
\hline$>10$ & 8 & 4.6 \\
\hline \multicolumn{3}{|c|}{ Monthly Per capita Health Expenditure (N) } \\
\hline$<500$ & 72 & 41.2 \\
\hline $500-1000$ & 77 & 44.0 \\
\hline $1001-1500$ & 17 & 9.7 \\
\hline$>1500$ & 9 & 5.1 \\
\hline
\end{tabular}

Source: Field Survey, 2014: Observation N = 175 
Table 1 shows that 97.7 per cent of the respondents are male-headed households within the ages of 30 to 60 years. Only a little above 10 per cent of them have postsecondary education with majority representing 37 per cent who have just primary education. 91.4 per cent of the respondents are married with a household size (adult equivalent) of between 3 and 6 persons. About 58 per cent have a farm size of less than 3 hectares which implies that most of them are subsistence farmers with an average farming experience of 22 years. Also, majority representing 62.3 per cent are not members of any form of cooperative society. The mean per capita income and monthly health expenditure of these households are N4452.55 and N676 respectively. This result is consistent with those of Babatunde et al (2011) for North-central Nigeria, Oyekale \&Eruwa (2009) for rural households in Osun State and Oriakhi \&Onemolease (2010) for Edo state.

\subsection{Hygeia Community Health Plan and Per Capita Income}

Table 2: Hygeia Community Health Plan and Per Capita Income

\begin{tabular}{lrrr}
\hline Variables & Coefficient & Standard Error & t-value \\
\hline Age (years) & -26.012 & 44.253 & -0.588 \\
Years of Schooling & 3.860 & 54.595 & 0.071 \\
Household size (AE) & $-1780.249 * * *$ & 179.616 & -6.003 \\
Farm size (hectares) & $966.484 * * *$ & 186.945 & 5.170 \\
Hygeia Health Plan (yes = 1) & $\mathbf{9 0 9 . 6 9 5 *}$ & $\mathbf{5 2 2 . 7 3 4}$ & 0.001 \\
Household Asset (N'000) & $0.003 * * *$ & 45.530 & $\mathbf{1 . 7 4 0}$ \\
Farm Experience (years) & 31.739 & 705.258 & 0.697 \\
Credit Access (yes = 1) & $1733.432^{* *}$ & 2.895 \\
Constant & $5354.719 * *$ & 2.458 \\
\hline
\end{tabular}

Source: Field Survey, 2014; *Significant at $p>0.10, * *$ Significant at $p>0.05 * * *$ Significant at $p>0.01, \mathrm{AE}=$ Adult Equivalent.

The Hygeia Health Plan, farm size, household asset and access to credit facilities were found to be positively significant at 10 per cent, 1 per cent and 5 per cent respectively. This implies that a beneficiary of the Hygeia health plan will have a higher per capita income of about 910 units compared to the non-beneficiaries. This is likely because a beneficiary of the health plan will be able to save more money thereby reducing outof-pocket expenses and increasing their per capita income. The farm size that was significant at 1 per cent implies that households with large farm size will be able to produce large output and as such realize more farm income. This will in-turn increase the per capita income compared to households with smaller farm sizes. This result is in consonance with that of Ibekwe (2010) for Imo state.

Access to credit and the household assets were also positively significant at 5 per cent and 1 per cent respectively. This implies that access to credit facilities and possession of more household asset will increase the potential to expand production activities thereby increasing their per capita income. The household size was found to be negatively significant at 1 per cent, which implies that large households will spend more thereby reducing the per capita income that will be available to them compared to smaller households. All this agrees with a priori expectations.

\subsection{Hygeia Community Health Plan and Per Capita Calorie Intake}

Table 3: Hygeia Community Health Plan and Per Capita Calorie Intake

\begin{tabular}{llll}
\hline Variables & Coefficient & Standard Error & t-value \\
\hline Age (years) & $24.608^{* *}$ & 11.6204 & 2.12 \\
Gender (male = 1) & 570.732 & 467.622 & 1.22 \\
Years of Schooling & -14.311 & 14.372 & 1.00 \\
Household size (AE) & -41.782 & 48.973 & -0.85 \\
Farm size (hectares) & $101.452^{* *}$ & 48.972 & 2.09 \\
Hygeia Health Plan (Yes = 1) & $\mathbf{1 0 8 3 . 4 7 1 * * *}$ & $\mathbf{1 4 0 . 7 0 5}$ & $\mathbf{7 . 7 0}$ \\
Farm Experience (years) & $20.687^{*}$ & 11.896 & 1.74 \\
Credit Access (yes = 1) & $396.254^{*}$ & 201.598 & 1.97 \\
Per Capita Expense & $0.053^{* *}$ & 0.026 & 2.05 \\
Total Asset & $0.001^{* * *}$ & 0.0003 & 2.09 \\
Constant & 828.3459 & 696.321 & 1.19 \\
\hline
\end{tabular}

Source: Field Survey, 2014; *Significant at $p>0.10, * *$ Significant at $p>0.05 * * *$ Significant at $p>0.01$ 
As shown in Table 3, the factors that were found to significantly influence the per capita calorie intake by farming households in the area are the age of household head, farm size, the Hygeia community health plan, years of farming experience, access to credit facilities, per capita expenditure and the total assets of the household. The age of the household head, farm size and per capita expenditure were positively significant at 5 per cent. This implies that older household head and those with larger farm size and higher per capita expenditure will in-turn consume more calories than the younger ones with smaller farm sizes. This may be because households with large farm sizes will be able to produce more thereby increasing their income and are in-turn able to spend more especially on food to stay healthy. This result is consistent with the findings of Orewa \& Iyanbe (2010).

Also, Hygeia community health plan and total household asset were positively significant at 1 per cent. This implies that all things being equal, a beneficiary of the Hygeia community health plan will increase its calorie consumption by 1083 units compared to a nonbeneficiary. This can be attributed to the fact that a beneficiary of the health plan spends less on healthcare services thereby able to save more. These savings can therefore be used in ensuring higher calorie intake. A non-beneficiary on the other hand is burdened with health expenditures which are paid mainly out-of-pocket with only little left for consumption purposes.

The years of farming experience and access to credit facilities were also positively significant at 10 per cent. This implies that, the more experienced the household head, the more he is able to ensure that farming activities are done efficiently and as such increasing output and calorie intake of his household. Also, increased access to credit facilities will also increase production and the financial capacity needed for the household to afford the required calorie intake. This is also consistent with the findings of Orewa \& Iyanbe (2010) for urban households in Nigeria.

\subsection{Variables' Ranking by Welfare indices}

Table 4: Variables' ranking by welfare indices

\begin{tabular}{llll}
\hline Variables & Low & Medium & High \\
\hline Per capita calorie (Kcal/AE/day) & 2318.90 & 3019.90 & 4129.90 \\
Monthly per capita income & 3595.00 & 4529.70 & 5247.50 \\
Total Household Asset (N'000) & 336 & 393 & 3333 \\
Farm Size (hectares) & 2.57 & 2.89 & 2.77 \\
Monthly Health expense & 2591.53 & 3110.34 & 2.860 .69 \\
Years of Schooling & 7.34 & 7.14 & 7.43 \\
\hline
\end{tabular}

Source: Field Survey, 2014; N = Naira, Kcal/AE/day = Kilocalorie/Adult Equivalent/day

Table 4 shows that households with low per capita calorie intake are characterized by low monthly per capita income, lower asset base and a relatively small (2.57 hectares) farm size. On the other hand, households with large asset base $(\mathrm{N} 3,333,000.00)$ were found to have a higher per calorie intake and a higher per capita income but they spend relatively small amount on health expenditure than those in the medium class. This might be because most of the households in the higher class are able to benefit from the health plan as oppose to the others. Therefore they have more to save since they spend less on healthcare.

\subsection{Hygeia community health plan and food security status}

Table 5: Hygeia community health plan and food security status

\begin{tabular}{l|l|l|l}
\hline Variables & Coefficient & Standard Error & t-value \\
\hline Age (years) & -0.0178 & 0.0251 & -0.71 \\
Per Capita Expense & $0.0001^{*}$ & 0.0000 & 1.83 \\
Years of Schooling & 0.0064 & 0.5003 & 0.13 \\
Household size (AE) & -0.0635 & 0.2001 & -0.32 \\
Farm size (hectares) & 101.4516 & 0.1654 & 0.73 \\
Hygeia Health Plan (Yes $=1)$ & $3.4944 * * *$ & 0.5780 & 6.38 \\
Constant & -1.2617 & 1.2733 & 0.99 \\
\hline Sout & &
\end{tabular}

Source: Field Survey, 2014; *Significant at $p>0.10, * *$ Significant at $p>0.05 * * *$ Significant at $p>0.01$ 
Table 5 shows that the Hygeia health plan was found to be positively significant, influencing the food security status of the households at 1 percent. This implies that, a beneficiary of the Hygeia health plan is more likely to be food secured than a non-beneficiary. This may be attributed to the fact that a beneficiary of the health plan would have been able to reduce out-of-pocket expenses. This would enable the household to spend more on food to complement own production so as to ensure food security.
The household's monthly per capita expenditure was also positively significant at 10 per cent. This implies that the more a particular household spends, the more it is likely to spend on food related items and hence become food secured. That is all things being equal, the more a household spends, the better are its chances of attaining food security. This result is similar to those of Bashir et al (2012) for Pakistan and Mitiku et al (2012) for Southern Ethiopia.

\section{CONCLUSIONS}

This study examined the effects of the Hygeia community health plan on farming households' welfare using the ordinary least square and the logit regression models. The major findings showed that the households that benefitted from the Hygeia community health plan had higher and significant per capita income, per capita calorie intake and were more food secured than those who did not. Other factors that were found to significantly influence the welfare of the farming households' are the age of the household head, household size, farm size, years of farming experience, total household asset, access to credit facilities and the per capita expenditure of the households. All these would result in a healthier workforce thereby increasing the production capacities of the farming households. This would lead to increase in household income and by extension generate improvement in households' welfare. Therefore, it is recommended that the design and implementation of community-based health plan should be encouraged for the rural farmers. Also, Nutritionoriented programs can be organized in an attempt to improve the food and dietary diversity of these rural people and the nation at large.

\section{REFERENCES}

Ajilowo, J. B. (2007). Accessibility of rural dwellers to health care facilities in Nigeria: The Owo region experience. Pakistan Journal of Social Sciences, 4 (1), 44-55.

Annear, P. (2006): "Study of Financial Access to Health Services for the Poor in Cambodia. Phnom Penh". Research report, Cambodia Ministry of Health, WHO, AusAID, RMIT University.

Ataguba, J. E., Ichoku, E. M., Fonta, M. W., Okpanachi, A. L. \& Okon, U. E. (2006). An Estimation of the Willingness to Pay for Community Healthcare RiskSharing Prepayment Scheme and the Medical Poverty Trap: Evidence from Rural Nigeria. A Paper Presented during the 5th PEPResearch Network General Meeting, June 18-22, Addis Ababa, Ethiopia.

Babatunde, O., Akande, T., Salaudeen, A., Aderibigbe, S., Elegbede, O. \& Ayodele, L. (2011). Willingness to pay for Community Health Insurance and Its determinants among Household heads in Rural communities in North central , Nigeria, International Review of Social Sciences and Humanities, 2(2) (2012), 133-142.

Bashir, M., Schilizzi, S. \& Pandit, R. (2012). The determinants of rural household food security: The case of Landless Households of the Punjab, Pakistan, Working Paper 1208, School of Agricultural and Resource Economics, University of Western Australia, Crawley, Australia.

Das, J., Hammer, J., and Leonard, K. (2008) "The Quality of Medical Advice in Low-Income Countries," Journal of Economic Perspectives, 22(2), 93-114. doi:10.1257/jep.22.2.93

Gertler, P., Levine, D., and Moretti, E. (2003). "Do Microfinance Programs Help Families Insure Consumption Against Illness?" Development and Comp Systems 0303004, Econ. WPA.

Ibekwe, U. C. (2010). Determinants of income among farming households in Orlu Agricultural Zone of Imo state, Nigeria. Report and Opinion 2010, 2(8), $32-35$.

Jansen, H. G. P, P. B. Siegel, J. Alwang \& F. Pichon (2005). Geography, Livelihoods and Rural Poverty in Honduras: An Empirical Analysis using an Asset-based Approach. Working Paper, No.134. Ibero-America Institute for Economic Research (IAI). Jans 
KWSG (2006). Planning studies in Kwara State. Kwara State Government of Nigeria, Ministry of land and Regional resources.

Mishra, S., (2007). Household Livelihood and Coping Mechanism during Drought among Oaron Tribe of Sundargarh District of Orissa, India. Journal of Social Science, 15 (2), 181 -186.

Mitiku A., Fufa B. \& Tadese B. (2012). Empirical analysis of the determinants of rural households food security in Southern Ethiopia: The case of Shashemene District. Basic Research Journal of Agricultural Science and Review, 1(6), 132-138.

NPC (2008). Nigerian Demographic and Health Survey Abuja, Nigeria.

Ogbimi, R.I (2004). Health consideration in rural development" Benin Journal of Education Studies, 18 (1 and 2), 163-175.

Orewa, S. \& Iyanbe, C. (2010). Determinants of Daily Food Calorie Intake among Rural and Low-Income Urban Households in Nigeria. Academic Journal of Plant Sciences, 3(4), 147-155.

Oriakhi, H. \& Onemolease, E. (2010). Determinants of Rural Household's Willingness to participate in Community-Based Health Insurance in Edo State,
Nigeria. Ethno Med, 6(2), 95-102. doi:10.1080/09735070.2012.11886425

Oyekale S. \& Eluwa C. (2009). Utilization of Healthcare and Health insurance among Rural Households in Irewole Local Government, Osun State, Nigeria. International Journal of Tropical Medicine, 4(2), 70-75,. ISSN: 1816-3319.

Rakodi, C. (1999). A capital assets framework for analysing household livelihood strategies: Implications for policy. Development Policy Review, 17, 315-342. doi:10.1111/14677679.00090

Smucker, Thomas A. \& Ben Wisner, (2008). Changing household responses to drought in Tharaka, Kenya: vulnerability, persistence and challenge. Journal Compilation at Overseas Development Institute, Blackwell Publishing. doi:10.1111/j.14677717.2007.01035.x

WHO (1997). The World Health Report: Making a difference. Geneva: World Health Organization.

World Bank (2005). World development report, World development indicators: Country: Nigeria. http://www.worldbank.org/external/countries/africa ext/nigeriaextn/. 